\title{
On the collections of Indo-Australian Spirobolida (Diplopoda) kept in the Zoological Museum of the Moscow State University, Russia. 4. A new species and a new record of Rhinocricidae from Papua New Guinea
}

\author{
O комлекџиях индо-австралийских Spirobolida (Diplopoda), \\ хранящихся в Зоологическом музее Московского \\ государственного университета (Россия). 4. ОАин новый виА \\ и новая находка Rhinocricidae из Папуа-Новой Гвинее
}

\author{
S.I. Golovatch ${ }^{1}$, J.-P. Mauriès ${ }^{2}$ \\ С.И. Головач ${ }^{1}$, ЖК.-П. Морьес ${ }^{2}$
}

${ }^{1}$ Institute for Problems of Ecology and Evolution, Russian Academy of Sciences, Leninsky prospekt 33, Moscow 119071 Russia. E-mail:
sgolovatch@yandex.ru
${ }^{1}$ Институт проблем экологии и эволюции РАН, Ленинский проспект, 33, Москва 119071 Россия.
${ }^{2}$ Muséum national d'Histoire naturelle, Departement de Systématique et Evolution, 61 rue Buffon, F-75231 Paris Cedex 05, France.

KEY WORDS: millipede, taxonomy, new species, iconography, New Guinea.

КЛЮЧЕВЫЕ СЛОВА: двупарноногие многоножки, таксономия, новый вид, иконография, Новая Гвинея.

ABSTRACT. The few remaining samples of Rhinocricidae from the southwestern Pacific kept in the Moscow Museum contain Eurhinocricus kurtschevae sp.n. and Dinematocricus aff. bionus Chamberlin, 1920, both described in detail and both coming from Papua New Guinea.

How to cite this paper: Golovatch S.I., Mauriès J.P. 2021. On the collections of Indo-Australian Spirobolida (Diplopoda) kept in the Zoological Museum of the Moscow State University, Russia. 4. A new species and a new record of Rhinocricidae from Papua New Guinea // Arthropoda Selecta. Vol.30. No.2. P.153159. doi: 10.15298/arthsel.30.2.02

РЕЗЮМЕ. Немногие оставшиеся пробы из семейства Rhinocricidae из юго-западной части Тихого океана, хранящиеся в Зоологическом музее в Москве, содержат Eurhinocricus kurtschevae sp.n. и Dinematocricus aff. bionus Chamberlin, 1920. Обе пробы детально описаны и происходят из ПапуаНовой Гвинеи.

\section{Introduction}

This is the fourth contribution to the fauna of the millipede order Spirobolida of the southwestern Pacific based on the collections of the Zoological Museum of the Moscow State University (ZMUM), Russia. Our previous contributions to the present series of papers dealt with some old or new Pachybolidae, Spirobolel- lidae and Rhinocricidae [Golovatch et al., 2020a, b, 2021]. This time we complete treating the remaining ZMUM material of Rhinocricidae which represents a new species and a new record from Papua New Guinea. These ZMUM samples were taken in 1976 and 1977 by Yuriy I. Chernov and Galina F. Kurcheva during two expeditions on board the research vessels "Kallisto" and "Dmitry Mendeleyev", respectively, to several islands and archipelagos in the southwestern Pacific.

According to the latest estimates [Golovatch et al., 2021], the family Rhinocricidae presently comprises 543 nominal species and 23 subspecies placed in 27 genera and three subgenera. The family is the largest in Spirobolida and shows two major distribution areas: one in the Americas where its species range from northern Argentina (but absent from Chile!) in the south to the Caribbean and northern Mexico in the north, and the other in the southwestern Pacific, including almost entire Indonesia, the Philippines, New Guinea, Micronesia, Melanesia, and eastern Australia [Marek et al., 2003]. The catalogue of the Indo-Pacific Spirobolida by Jeekel [2001] is still fully relevant as regards Rhinocricidae. Because about half of the $170+$ species or subspecies from nine formal rhinocricid genera hitherto reported from Australasia are completely dubious, most of the identifications of the Rhinocricidae species kept in the ZMUM remain provisional [Golovatch et al., 2021]. Below we dare describe a new species and provide a new record of another one, both from Papua New Guinea. 


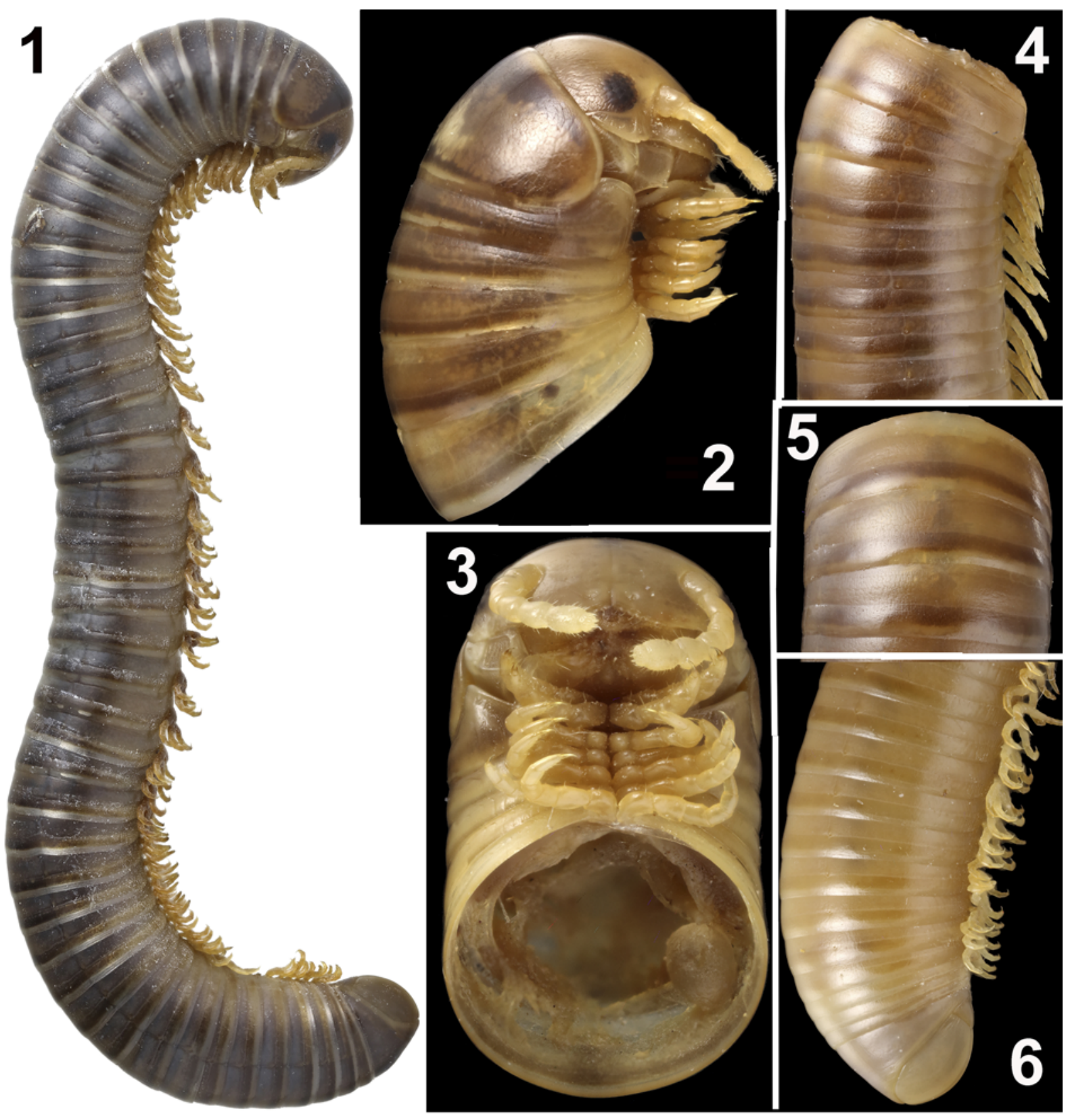

Figs 1-6. Eurhinocricus kurtschevae sp.n., $0^{7}$ holotype (1) and $0^{7}$ paratype (2-6) from Port Moresby. 1 - habitus, lateral view; 2, 3 anterior part of body, lateral and ventral views, respectively; 4, 5 - midbody segments, lateral and dorsal views, respectively; 6 posterior part of body, lateral view. Pictures by K.V. Makarov, taken not to scale.

Pис. 1-6. Eurhinocricus kurtschevae sp.n., голотип О7 (1) и паратип О7 (2-6) из Port Moresby. 1 - общий вид, сбоку; 2, 3 передняя часть тела, соответственно сбоку и снизу; 4,5 - среднетуловищные сегменты, соответственно сбоку и сверху; 6 задняя часть тела, сбоку. Фотографии К.В. Макарова, сняты без масштаба.

\section{Material and methods}

All new material treated below is deposited in the ZMUM. Colour pictures were obtained with a Canon EOS 5D digital camera and stacked using Zerene Stacker software.

The classification, however deficient, follows that of Jeekel [2001] and Minelli [2015], allowing for catalogue sections to largely be omitted as redundant.

\section{Taxonomic part}

Genus Eurhinocricus Brölemann, 1903

Type species: E. biolleyi Brölemann, 1903, by monotypy.

COMMENT. This rather large genus of Rhinocricidae presently comprises 34 species or subspecies which are mostly endemic to South and Central America, ranging from Brazil 


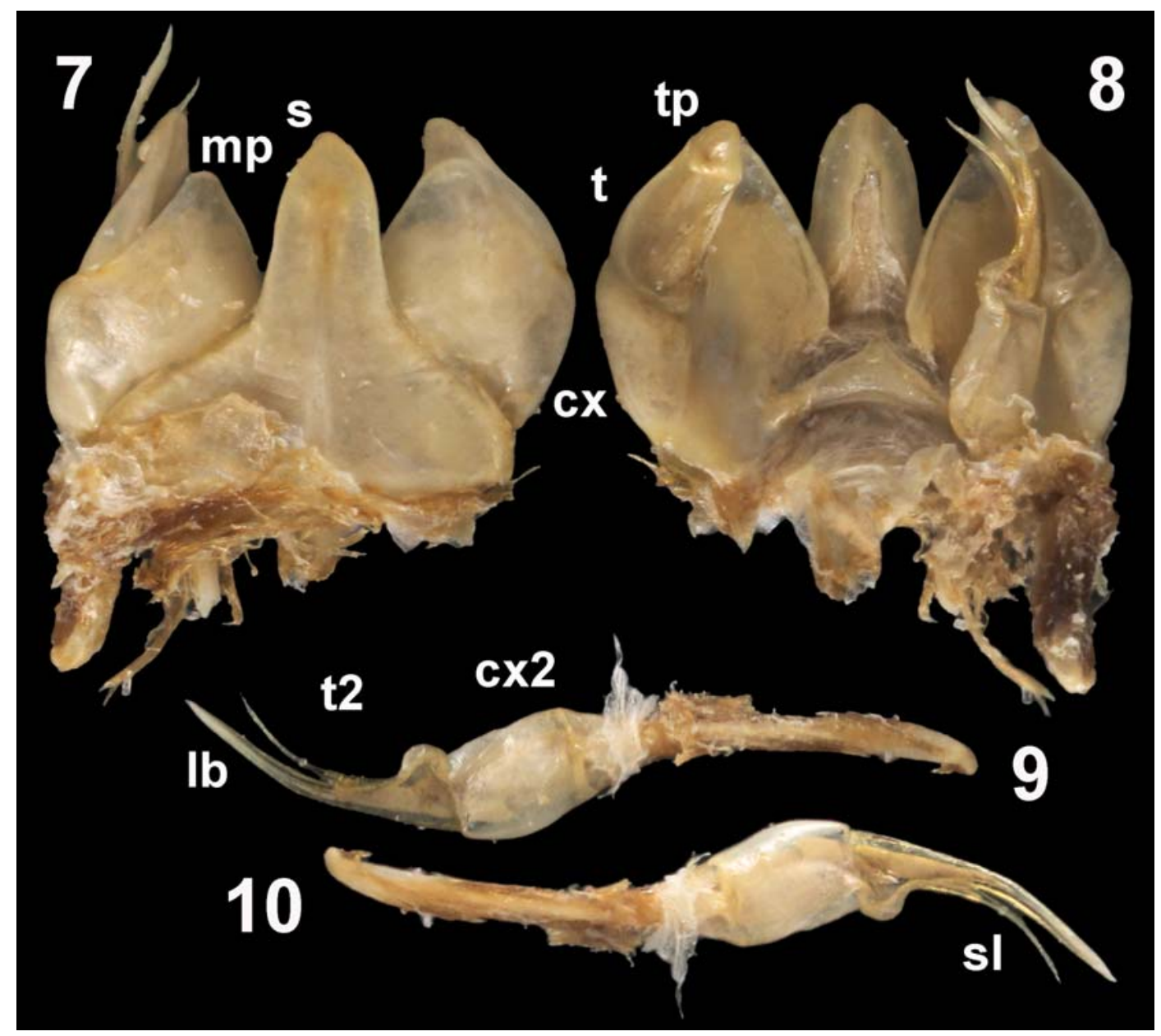

Figs 7-10. Eurhinocricus kurtschevae sp.n., $0^{7}$ paratype. 7, 8 - anterior gonopods, anterior and posterior views, respectively; 9 , 10 - isolated right posterior gonopod, anterior and posterior views, respectively. Designations explained in text. Pictures by K.V. Makarov, taken not to scale.

Рис. 7-10. Eurhinocricus kurtschevae sp.n., паратип О7.7, 8 - передние гоноподы, соответственно спереди и сзади; $9,10-$ изолированный правый задний гонопод, соответственно спереди и сзади. Объяснения обозначений в тексте. Фотографии К.В. Макарова, сняты без масштаба.

and Bolivia in the south to northern Mexico in the north (also introduced to the southern U.S.A.) [Jeekel, 2001; Marek et al., 2003; https://bugguide.net/node/view/103681]. Only two species are remarkable exceptions, one from the Caroline Islands and the other from the Marianas, both in Micronesia [Jeekel, 2001]. Following both Attems [1914] and Hoffman [1955], this tetraconocerate genus is distinguished through the structure of the posterior gonopod, in which the solenomere is a shorter mesal branch, while the main, outer branch is flattened, apically usually subtruncate, but never truly flagelliform.

\section{Eurhinocricus kurtschevae sp.n.} Figs 1-10.

HOLOTYPE $\sigma^{7}$ (ZMUM), Papua New Guinea, near Port Moresby, $\mathrm{S} 9^{\circ} 28^{\prime}, \mathrm{E} 147^{\circ} 09^{\prime}$, forest edge near bay, 20.I.1977, G.F Kurcheva leg.

PARATYPES: $3 \sigma^{\top} \sigma^{\top}, 2$ 90,3 juv. (ZMUM), same data, together with holotype.
DIAGNOSIS. Differs from congeners primarily by the unusually sharp and needle-shaped tip of the main branch (lb) of the posterior gonopod.

DESCRIPTION. Length $26-29 \mathrm{~mm}$, width ca. $3.0 \mathrm{~mm}$ $\left(\sigma^{7},+\right)$. Holotype $29 \mathrm{~mm}$ long. Adults with $39-44 p+1-$ $3 \mathrm{ap}+\mathrm{T}$ segments, holotype with $42 \mathrm{p}+1+\mathrm{T}$ segments. Colouration light yellowish (apparently faded due to longterm preservation in ethanol) to dark grey-brown, more vivid until about midbody part, usually increasingly lighter towards a light brown telson (Figs 1-6); pattern cingulate, usually distinct due to yellowish prozonae and darker brown metazonae (except for fully transparent and sometimes amber reddish caudal margins); head and several following segments vaguely marbled, head sometimes infuscate (brown) along axial suture; collum broadly (to $1 / 4$ ) brown along anterior margin and more narrowly brown along lateral and, especially, caudal margins; eye patches dark brown; legs lighter, yellowish to distally light brown or reddish. Axial stripe on dorsum grey, narrow, dark and usually flanked by vague, broader and lighter stripes (Figs $1-6)$. 

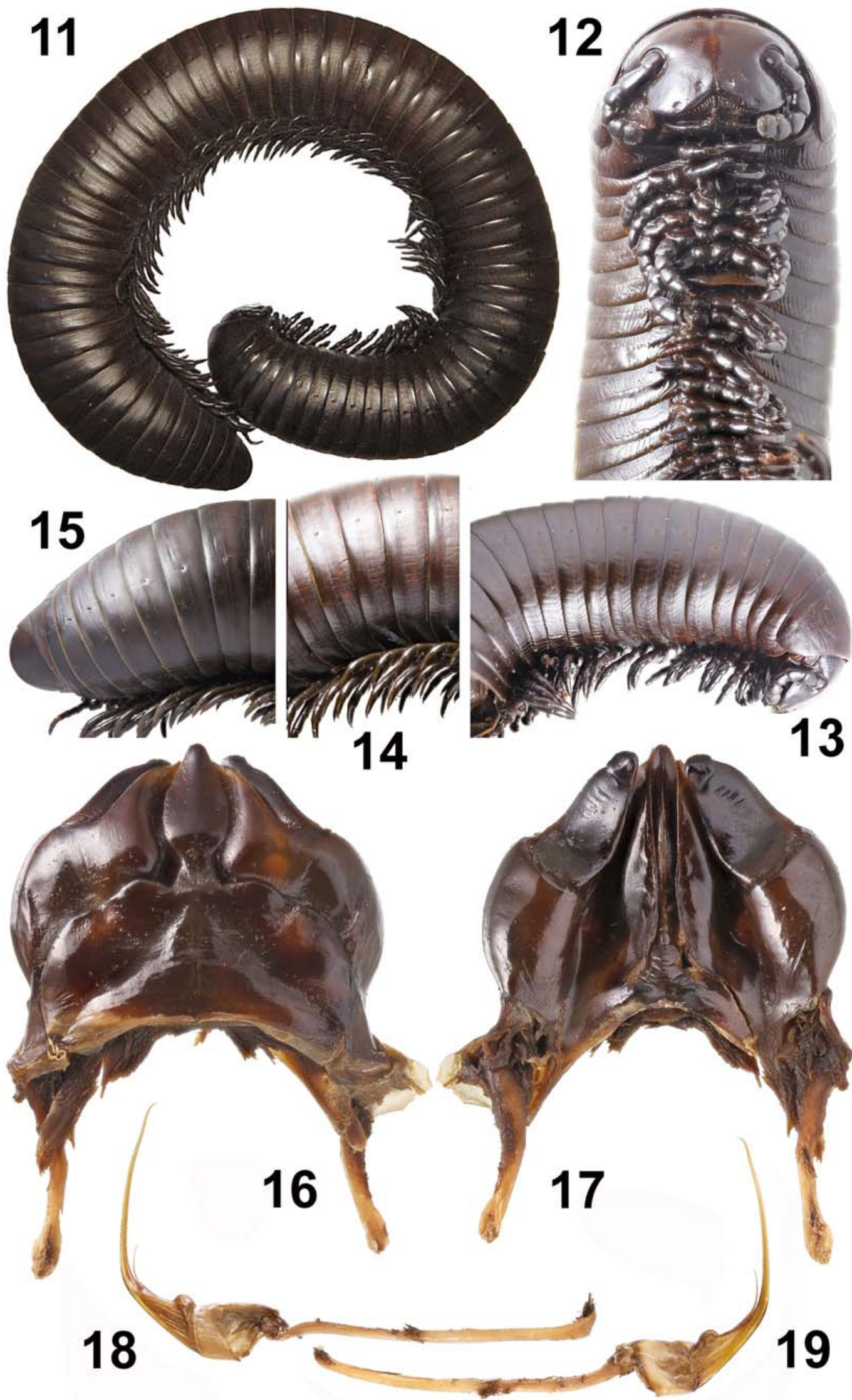
Body cylindrical, postcollum contriction very faint (Fig. 3 ). Head as usual, three small central teeth at fore margin of and a superficial, fine, axial suture on labrum, with ca. $10+10$ labral and $2+2$ supralabral setae. Eye fields subcircular, large, ommatidia flat, ca. $25-37$ per patch $(2+5+6+6+6$ to $3+6+7+7+7+7)$, arranged in 5-6 vertical rows (Figs 1, 2), isthmus $>2 \mathrm{x}$ diameter of eye patch (Fig. 3). Antennae short and clavate, a little longer in $\sigma^{7}$ compared to $q$, curved anteroventrad; antennomeres 1-6 subequal in length, antennomeres $5-7$ densely setose, $4^{\text {th }}$ setose only near distal end, $7^{\text {th }}$ the shortest, $8^{\text {th }}$ with four small apical cones (Figs 1-3). Tegument bare, smooth and mostly shining, finely punctured and incised (Figs 1-6). Collum very broadly rounded, indistinctly bordered with a short furrow only anterolaterally (Figs.1, 2). Midbody segments/rings devoid of evident transverse sutures between zonae; meso- and metazonae more distinctly and densely striate ventrad, less regularly striolate until about ozopore level, longitudinal on metazonae, slightly oblique and directed dorsad on mesozonae, very delicate, dense, vertical and often confused on prozonae; dorsal surface of meso- and metazonae nearly bare (Figs 1-6)). Scobinae present, small, divided by ca. 1.5 their own width, with evident caudal fields (Fig. 4). Ozopores small, inconspicuous, starting with segment/ring 6 , each pore lying upon line/suture just before metazona on a vague and minute boss. Telson (Figs 1, 6) as usual, epiproct flat, caudally rounded and very small; paraprocts strongly and regularly convex, smooth, not bordered along caudal margin, with only a small and inconspicuous gutter between both valves; hypoproct strongly transverse and caudally rounded. Only $\sigma^{7}$ segment 7 clearly swollen ventrally (Fig. 1), a complete ring due to a strong ventral bridge in caudal half. Very small and numerous, light and irregular spots/sigilla on internal surface of meso- and metazonae (Fig. 3).

Legs short and slender, ca. $1 / 2\left(O^{7}\right)$ to $1 / 3(+)$ as long as midbody height, each usually with a spine below and above claw; only ol legs 1 and 2 somewhat shorter; ventral sole pads wanting (Fig. 3).

Gonopods (Figs 7-10). Anterior gonopods (Figs 7, 8) with a strong, median, subacuminate, finger-shaped, apically rounded, sternal process (s), the latter about as long/high as both coxa (cx) and telopodite (t) with its small, apical, rounded, laterally directed process (tp); cx the largest, with a strong, mesal, subtriangular and apically rounded projection ( $\mathbf{m p})$ subtending a relatively slender $\mathbf{t}$ on anterior and mesal sides. Posterior gonopods (Figs 9, 10) connected through a small, membranous, ribbon-shaped sternum, each gonopod consisting of a stout subcylindrical coxa (cx2) and a slender, unusually only slightly longer, bipartite telopodite (t2); apicolateral branch (lb) the largest, slender, flattened, acuminate and slightly curved in distal half; mesal branch (= solenomere, sl) flagelliform, only a little shorter than $\mathbf{l b}$ and originating near basal $1 / 5$ of $\mathbf{t} 2$.

REMARKS. The assignment of this new species to $E u$ rhinocricus Brölemann, 1903 is not too straightforward, because the tip of the main branch (lb) of its posterior gonopod is sharp and needle-shaped like in species of the other genera of Rhinocricidae, but is neither blunt nor expanded, nor leaf-shaped as in the other, more typical species of Eurhinocricus. However, since lb in E. kurtschevae sp.n. is clearly flattened and non-flagelliform, we tend to regard the new species as a member of Eurhinocricus. As the geographically closest record belongs to a closer unidentified congener from Fiji, Melanesia [Golovatch et al., 2021], E. kurtschevae sp.n. is the first congener to be reported from New Guinea. Its position somewhat intermediate between the more typical Eurhinocricus and the numerous Dinematocricus species in the region is noteworthy.

\section{Dinematocricus aff. bionus Chamberlin, 1920} Figs 11-21.

MATERIAL. $2 \sigma^{7} \sigma^{7}$ (ZMUM), Papua New Guinea, S6 $6^{\circ} 44^{\prime} 0^{\prime \prime}$, E147 $0^{\prime} 0^{\prime \prime}$, Port Lae, park, leaf litter, 10.XII.1977, Yu.I. Chernov leg.

DESCRIPTION. Body ca. 175 or $120 \mathrm{~mm}$ long, width or height of midbody segments $13-14 \mathrm{~mm}$, with $60 \mathrm{p}+\mathrm{T}$ or $43 p+T$ segments. Colouration uniformly blackish to blackred-brown, head, antennae, legs, gonopods and telson dark red-brown; limbus often amber reddish yellow (Figs 11-15).

Body cylindrical, postcollum constriction very faint (Fig. 12). Head as usual, bare, with three small, but evident, central teeth at fore margin of, and a short, axial and distinct suture on, labrum, followed by a long, more superficial, fine, axial, epicranial line, with ca. $12+12$ labral and $2+2$ supralabral setae. Eye patches suboval, large and blackish (Figs 11, 13), each composed of ca. 34-38 flat ommatidia arranged in six vertical rows (e.g., ca. $8+7+7+7+6+4$ ); interantennal isthmus ca. 2.5x diameter of eye patch (Fig. 12). Antennae short and clavate, curved anteroventrad, in situ stretchable laterally behind caudal margin of collum; in length, antennomere $2>3>4=5=6>1>7$; antenomeres 57 clothed with particularly dense, but mostly short setae; $8^{\text {th }}$ with four small apical cones (Figs 12, 13). Tegument bare, almost smooth, very finely leathery, mostly shining (Figs 11-15). Collum broadly rounded and very narrowly bordered along anterior and lateral margins, more narrowly rounded and subangular at caudolateral corner; an oblique and irregular line/scratch above, a shorter longitudinal scratch at base, and a transverse scratch at ca. 1/5 off caudal margin of collum (Fig. 13). Segment/ring 2 with a conspicuously flattened and subvertically striolate anteroventral part to subtend collum. Midbody segments/rings devoid of evident sutures between zonae, very poorly constricted only between meso- and metazonae; dorsum very faintly and vaguely striolate starting already with ring 2 , following meso- and metazonae increasingly smooth in/towards caudal body quarter; striations on meso- and metazonae increasingly deep, clear and dense ventrolaterad (Figs 11-15). Scobinae present, small paramedian lunulae with posterior fields, separated by about their own width at anterior margin of prozonae, starting with ring 8 and persisting at least until midbody rings. Ozopores small round disks lying at fore margin of metazonae on all leg-bearing segments starting with segment 6

Figs 11-19. Dinematocricus aff. bionus Chamberlin, 1920, $0^{\top}$ from Lae. 11 - habitus, lateral view; 12,13 - anterior part of body, ventral and lateral views, respectively; 14, 15 - midbody segments and posterior part of body, respectively, lateral views; 16, 17 anterior gonopods, anterior and posterior views, respectively; 18, 19 - isolated right posterior gonopod, anterior and posterior views, respectively. Pictures by K.V. Makarov, taken not to scale.

Рис. 11-19. Dinematocricus aff. bionus Chamberlin, 1920, о7 из Lae. 11 - общий вид, сбоку; 12, 13 - передняя часть тела, соответственно снизу и сбоку; 14,15 - соответственно среднетуловищные сегменты и задняя часть тела, сбоку; $16,17-$ передние гоноподы, соответственно спереди и сзади; 18,19 - изолированный правый задний гонопод, соответственно спереди и сзади. Фотографии К.В. Макарова, сняты без масштаба. 


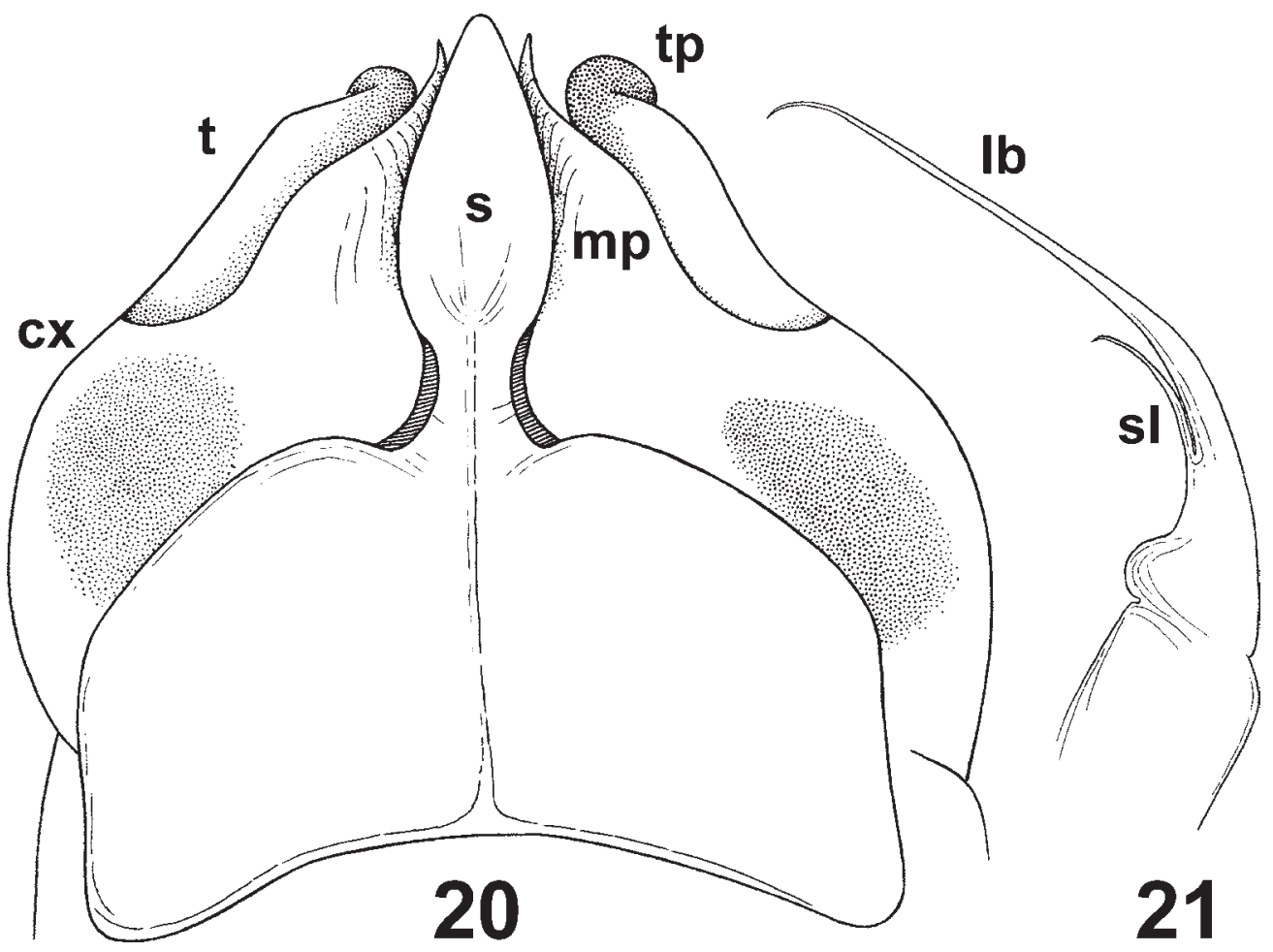

Figs 20, 21. Dinematocricus aff. bionus Chamberlin, 1920, $0^{7}$ from Lae. 20 - anterior gonopods, anterior view; 21 — right posterior gonopod, anterior view. Designations explained in text. Drawn not to scale.

Рис. 20, 21. Dinematocricus aff. bionus Chamberlin, 1920, О7 из Lae. 20 - передние гоноподы, спереди; 21 - правый задний гонопод, спереди. Объяснения обозначений в тексте. Нарисовано без масштаба.

(Figs 11, 13-15). Telson (Figs 11, 15) as usual, epiproct flat, small, digitiform, rounded caudally; paraprocts very strongly and regularly convex, smooth, very poorly bordered into swollen caudal lips with a usual gutter between both valves; hypoproct nearly semi-circular, strongly transverse, rounded caudally. Only $\sigma^{7}$ segment 7 clearly swollen ventrally, a complete ring due to a strong, ventral, subvertical bridge in caudal half (Fig. 12). No visible sigilla on internal surface of meso- and metazonae.

Legs short and slender, ca. $1 / 2$ as long as midbody height $\left(O^{7}\right)$, each tarsus usually with a spine above and 2-3 below claw; only $O^{7}$ legs 1 and 2 somewhat shorter; $O^{7}$ coxae 3-5 clearly expanded ventrally, rounded tubercles being more evident on coxae 3 , but lower on coxae 5; coxae, prefemora and femora, sometimes also postfemora and tibiae, all densely, finely and subvertically ribbed/striate, following podomeres swollen ventrally, but not padded, each podomere before tarsus with a strong ventral seta; claws stout, short and curved ventrad (Fig. 12).

Gonopods strongly sclerotized (Figs 16-21). Anterior gonopods with a strong, spear-shaped, central, distally broadened and apically narrowly rounded, sternal process (s), the latter being longer/higher than both coxa (cx) and telopodite (t) with its small, apical, rounded, caudolateral process (tp); cx stout, with a high, elongate, mesal, subtriangular projection ( $\mathbf{m p}$ ) with its sharp tip; $\mathbf{t}$ more slender than $\mathbf{c x}$. Posterior gonopods consisting of a shorter, relatively stout, subcylindrical coxa and a slender, much longer, bipartite telopodite; apicolateral branch (lb) the longest, $>3 \mathrm{x}$ as long as a similarly flagelliform solenomere (sl).
REMARKS. Among the very numerous Dinematocricus species listed by Jeekel [2001], there is a group of congeners that are easily distinguished by the anterior gonopods showing a conspicuous and spear-shaped central sternal process: D. carinatus (Karsch, 1881), D. lanceolatus Brölemann, 1913, D. philistus (Attems, 1914), D. repandus Attems, 1914 and D. strobilus Attems, 1914 [Brölemann, 1913; Attems, 1914, 1915, 1917], all of them from New Guinea and/or adjacent archipelagos. As demonstrated recently [Golovatch et al., 2021], D. bionus Chamberlin, 1920 is also likely to join that group. All such species are so similar to one another [Golovatch et al., 2021] that looking for an exact match is more or less useless. The more so as the gonopods in adult $\bigcirc^{7} \sigma^{7}$ of Rhinocricidae are long known to grow gradually from one molt to the next and often tend to get modified in the course of hemianamorphosis [Mauriès, 1980; Enghoff et al., 1993; Bond et al., 2003].

Following our cautious approach to naming new samples of Rhinocricidae from the southwestern Pacific, we again prefer to leave the above material unidentified closer and not to describe it as a new species. Moreover, a full illustrated description of $D$. aff. bionus using a strict topotype from Bio Island, Solomons, is readily available for comparative purposes [Golovatch et al., 2021].

Acknowledgements. The colour pictures were very skillfully taken by Kirill V. Makarov, Moscow, Russia. The first author was partly supported by the Presidium of the Russian Academy of Sciences, Program No. 41 "Biodiversity of natural systems and biological resources of Russia". 


\section{References}

Attems C. 1914. Die indo-australischen Myriopoden // Archiv für Naturgeschichte. Jg.80A. H.4. S.1-398.

Attems C. 1915. Myriopoden von Ceram und Waigeu gesammelt von L. F. de Beaufort i. J. 1909 // Bijdragen tot de Dierkunde. Deel 20. S.1-12.

Attems C. 1917. Myriopoden von Neu-Guinea gesammmlt während der Expedition 1903 // Nova Guinea. Bd.5. S.567-587.

Bond J.E., Beamer D.A., Hedin M.C., Sierwald P. 2003. Gradual evolution of male genitalia in a sibling species complex of millipedes (Diplopoda: Spirobolida: Rhinocricidae: Anadenobolus) // Invertebrate Systematics. Vol.17. P.711-717.

Brölemann H.W. 1913. The Myriapoda in the Australian Museum Part ii - Diplopoda // Records of the Australian Museum. Vol.10. No.6. P.77-158.

Enghoff H., Dohle W., Blower J.G. 1993. Anamorphosis in millipedes (Diplopoda) — the present state of knowledge with some developmental and phylogenetic considerations // Biological Journal of the Linnean Society. Vol.109. P.103-234.

Golovatch S.I., Mauriès J.-P., Akkari N. 2020a. On the collections of Indo-Australian Spirobolida (Diplopoda) kept in the Zoological Museum of the Moscow State University, Russia. 1. A new species of Arisemolus Hoffman, 1980 from Papua New Guinea // Arthropoda Selecta. Vol.29. No.3. P.309-315.
Golovatch S.I., Mauriès J.-P., Akkari N. 2020b. On the collections of Indo-Australian Spirobolida (Diplopoda) kept in the Zoological Museum of the Moscow State University, Russia. 2. Two new species of Spirobolellus Pocock, 1894 from islands off Papua New Guinea and Australia // Arthropoda Selecta. Vol.29. No.4. P.399-407.

Golovatch S.I., Mauriès J.-P., Akkari N. 2021. On the collections of Indo-Australian Spirobolida (Diplopoda) kept in the Zoological Museum of the Moscow State University, Russia. 3. Some Rhinocricidae // Arthropoda Selecta. Vol.30. No.1. P.327.

Hoffman R.L. 1955. Studies on spirobolid millipeds. II. A second paper on the genus Eurhinocricus // Proceedings of the Biological Society of Washington. Vol.68. P.31-36.

Jeekel C.A.W. 2001. A bibliographic catalogue of the Spirobolida of the Oriental and Australian regions (Diplopoda) // Myriapod Memoranda. Vol.4. P.5-104.

Marek P.E., Bond J.E., Sierwald P. 2003. Rhinocricidae systematics II. A species catalog of the Rhinocricidae (Diplopoda: Spirobolida) with synonymies // Zootaxa. Vol.308. P.1-108.

Mauriès J.-P. 1980. Diplopodes Chilognathes de la Guadeloupe et ses dépendances // Bulletin du Muséum national d'Histoire naturelle, Paris. Série 4. T.2, section A. No.4. P.1059-1111.

Minelli A. (ed.). 2015. Treatise on Zoology - Anatomy, Taxonomy, Biology. Vol.2. The Myriapoda. Brill: Leiden - Boston. 482 pp.

Responsible editor K.G. Mikhailov 